\title{
Association Between the Food Security Status and Dietary Patterns With Polycystic Ovary Syndrome (PCOS) in Overweight and Obese Iranian Women: A Case-Control Study
}

\author{
Mahtab Badri-Fariman \\ Tehran University of Medical Sciences \\ Amirmansour Alavi Naeini \\ Isfahan University of Medical Sciences \\ Khadijeh Mirzaei \\ Tehran University of Medical Sciences \\ Ashraf Moeini \\ Tehran University of Medical Sciences \\ Mostafa Hosseini \\ Tehran University of Medical Sciences \\ Seyedeh Elaheh Bagheri \\ Guilan University of Medical Sciences \\ Milad Daneshi-Maskooni ( $\square$ miladdaneshi@gmail.com ) \\ Jiroft University of Medical Sciences https://orcid.org/0000-0003-1373-1358
}

\section{Research}

Keywords: Food security, Dietary pattern, Polycystic ovary syndrome, Obesity

Posted Date: June 2nd, 2021

DOI: https://doi.org/10.21203/rs.3.rs-549311/v1

License: (c) (i) This work is licensed under a Creative Commons Attribution 4.0 International License. Read Full License 


\section{Abstract \\ Background}

Polycystic ovary syndrome (PCOS) as one of the major types of endocrine disorders is common among women worldwide. Frequently reported that food insecurity $(\mathrm{FI})$ and unhealthy diets can exert negative effects on reproductive health. There are contradictory results on optimal lifestyle modification especially dietary components with PCOS. This paper aimed to assess the association between PCOS with food security status and dietary patterns of overweight and obese Iranian women.

\section{Methods}

This case-control study was performed on 240 overweight and obese adult women with PCOS $(n=120)$ and without PCOS $(n=120)$ referred to the infertility clinic of Arash Hospital in Tehran, Iran. Participants' data on anthropometry, scio-economic factors, and physical activity were collected. Food security status and dietary intakes were assessed by validated questionnaires.

\section{Results}

The prevalence of $\mathrm{FI}$ was $60 \%$ in women with PCOS and $30 \%$ in healthy women. There was a positive association between the risk of PCOS with $\mathrm{Fl}$, quasi-western dietary pattern, low economic level, waist circumference, and menstrual age and a negative association between physical activity and healthy dietary pattern with this risk even after controlling the potential confounders $(P<0.05)$. PCOS women had a higher intake of saturated fats, monounsaturated fats, oleic acid, fluorine, sucrose, and caffeine and a lower intake of vitamins $A, B_{5}, B_{6}, B_{12}, C$, and $D$, potassium, proteins, carbohydrates, cholesterols, docosahexaenoic acid, potassium, carotenes, lutein, beta-cryptoxanthin, lycopene, calcium, iron, thiamine, riboflavin, niacin, tetra- and dihydrofolate, biotin, phosphorus, magnesium, zinc, copper, total, insoluble, and crude fiber, glucose, galactose, fructose, and lactose compared to the healthy group $(P<0.05)$.

\section{Conclusions}

$\mathrm{Fl}$, quasi-western dietary pattern, low economic status, and waist circumference were significantly associated with the higher risk of PCOS. Modifying lifestyle especially in dietary patterns may be an important strategy for the reduction of PCOS. Future prospective studies are warranted to confirm these findings and to identify the underlying mechanisms.

\section{Introduction}

Polycystic ovary syndrome (PCOS) as one of the main health challenges worldwide [1] is the most prevalent and complex type of endocrine disorder among women of reproductive age [2-7]. According to 
Rotterdam criteria, this syndrome affects $19.5 \%$ of Iranian women $[8,9]$. PCOS is characterized by polycystic ovarian morphology (PCOM) [3, 10], ovulatory dysfunction [4, 10-12], menstrual disorders [2, 4, $13]$, reproductive problems, infertility $[3,4,14,15]$, oligomenorrhea [12, 15], hyperandrogenism $[2,4,10-$ $12,15]$, and some clinical manifestations of alopecia, acne, oily skin, and hirsutism [2, 3, 12-14]. Moreover, several complications including insulin resistance (IR) $[9,12-14,16-18]$, type 2 diabetes (T2DM) $[11-13,18,19]$, cardiovascular disease (CVD) $[3,9,11,13,14,17]$, endometrial cancer $[3,11,19]$, mental and behavioral disorders (e.g., anxiety, depression, lack of self-confidence) [12, 20], dyslipidemia $[13,14,16,18]$, metabolic syndrome $[9,17,18]$, and specifically obesity $[13,14,16]$ are associated with not-treated PCOS. It is estimated that nearly $40-60 \%$ of PCOS women are overweight or obese [2].

Generally, the etiology of PCOS is very complex and not well clear, but refers to multifactorial causes which can be genetic or modifiable factors such as environment $[2,8,9,21,22]$ and lifestyle factors i.e. smoking [2], physical activity [2, 3, 23], and diet [2, 8, 9, 21, 23]. However, inappropriate lifestyle particularly unhealthy dietary pattern results in IR and obesity $[8,24]$ which are considered as most common etiological factors of this syndrome $[3,25]$. So, lifestyle modification especially considering the reduction of IR and obesity may also have a key role in the treatment of PCOS [1].

Dietary patterns not only have a potentially positive effect on IR and overweight $[26,27]$ but also can influence the expression of genes involved in critical metabolic pathways [28]. It is indicated that Iranian women with a higher risk of PCOS had higher western dietary patterns and a lower intake of plant-based diets [8]. Qualitative or quantitative dietary deficiencies have been reported to be related to the higher weight that can lead to the occurrence or progression of PCOS [29].

In addition, food insecurity $(\mathrm{Fl})$ is considered as a condition that there is limited access to an adequate healthy diet which can cause a wide spectrum of socio-emotional issues, obesity, and chronic disorders $[30,31]$ that may be affected by several socio-economic factors [32]. Nowadays, almost 795 million persons suffer from $\mathrm{FI}$ around the world [33]. It is estimated that 25 and 50 percent of Iranian women have energy restriction and nutritional deficiencies, respectively [34]. Since the prevalence of FI in Iran is increasing, preventive approaches are needed to reduce their adverse ongoing results [35].

Evidence suggests that a combination of the nutritional components in the form of healthy dietary pattern has a significant beneficial effect on both prevention and treatment of PCOS [36] that probably be due to their impact on the numbers of metabolic and inflammatory factors [37]. Dietary approaches to stop hypertension (DASH) diet as a kind of dietary pattern which is rich in fruits, vegetables, whole grains, and low-fat dairy products and low in carbohydrates, saturated fats, and cholesterol has a beneficial effect on the body mass index (BMI) [18, 38], antioxidant status [38], IR, and nitric oxide [18] in overweight or obese PCOS women. A recent study demonstrated the negative association between the severity of inflammatory profiles, IR, and hyperandrogenemia with the Mediterranean diet (MD) in women with PCOS [39]. Negative and positive associations were reported between the intakes of high glycemic index (GI) diet and anti-inflammatory dietary pattern with the risk of PCOS, respectively [9]. Also, it was reported that total dietary intake of protein and energy intake of simple sugars are significantly lower in PCOS rather 
than in healthy women [40]. However, there were no significant differences in the dietary intakes of PCOS and healthy women in another study [41]. Babapour et al. negatively indicated the relationship between serum levels of magnesium with the development of PCOS among overweight or obese women [10]. Although, another researcher failed to find any positive effects of magnesium supplementation on the serum lipid and glycemic indicators [42]. On the other hand, supplementation with dietary intakes of fiber and magnesium was related to lower IR and hyperandrogenemia [43]. However, the optimal diet is not yet well-understood and its overall impact on the risk of PCOS mainly remains unknown $[1,19]$.

Taken together, no study has assessed the relationship between both food security status and dietary patterns with PCOS. Therefore, this paper aimed to investigate the association between PCOS with food security status and dietary patterns of overweight and obese Iranian women referred to the infertility clinic in Tehran, Iran.

\section{Methods}

\section{Study design and population}

This case-control study was carried out on overweight and obese Iranian adult women referred to the infertility clinic of Arash Hospital, Tehran, Iran. The inclusion criteria for the case group were the diagnosis of PCOS based on the presence of PCOM on ultrasound according to the doctor's confirmation or standard Rotterdam-based diagnosis [44] during less than six months before the study, age between 20 and 48 years, and BMI equal to or more than 25-kilogram per meter square $\left(\mathrm{kg} / \mathrm{m}^{2}\right)$. The control group in this study were the age-matched women without PCOS and with BMI equal to or more than $25 \mathrm{~kg} / \mathrm{m}^{2}$ and normal 26-33 days menstrual pattern. The exclusion criteria were included the current history of cardiovascular, liver, and/or kidney diseases, smoking, taking drugs that can affect the metabolism of hormones and body composition, having severe physical activities, and not consent to participate in the study.

At first, a pre-test was performed on women with PCOS $(n=20)$ and healthy non-PCOS women $(n=20)$ to get them acquainted with the research environment, manner of responding to questionnaires, determining sample size, and accuracy of the study. According to the performed pre-test, the percentage of FI was obtained $30 \%\left(P_{1}=0.30\right)$ for healthy individuals and $55 \%\left(P_{2}=0.55\right)$ for PCOS women. The sample size was calculated 102 by the following formula.

$$
\begin{aligned}
& \mathrm{n}=\frac{2\left(\mathrm{Z}_{1-\alpha / 2}+\mathrm{Z}_{1-\beta}\right)^{2} \times[\overline{\mathrm{P}}(1-\overline{\mathrm{P}})]}{\left(\mathrm{P}_{1}+\mathrm{P}_{2}\right)^{2}} \\
& \overline{\mathrm{P}}=\frac{\mathrm{P}_{1}+\mathrm{P}_{2}}{2} \\
& \mathrm{P}_{1}=30 \%, \mathrm{P}_{2}=55 \%, \mathrm{a}=\beta=0.05
\end{aligned}
$$


However, in order to reliability and the probability of sample loss, the sample size was raised to 120 . Since the dietary pattern is affected by $\mathrm{Fl}$, so food security variable was considered as the main factor for calculating the sample size. Finally, data analysis was done on 240 women who met the criteria of the study including 120 women with a definitively PCOS diagnosis as the case group and 120 similar healthy participants as the control group (Fig. 1).

\section{Data collection}

After full explanations of the goals and method of the study and receiving the written consent form, data on general characteristics (anthropometry and scio-economic factors), physical activity, food security status, and dietary patterns were collected from all participants using valid and reliable questionnaires through face-to-face interviews and some measures.

\section{General Characteristics}

Data on anthropometry and scio-economic factors were assessed by general questionnaire included questions about age, ethnicity, levels of education and economic, job status, numbers of family members and employed persons of household, the status of insurance support, house ownership, and marriage, menstrual age, and numbers of pregnancy and child. Also, additional assessment in the case group was performed using a self-reported questionnaire that included some signs and symptoms of PCOS. The weight of the participant was measured using a Seca scale with minimal clothing and without shoes with an accuracy of 0.1 kilograms $(\mathrm{kg})$ and height was measured using a wall attached tape meter with an accuracy of 0.5 centimeters $(\mathrm{cm})$. Then BMI was calculated by dividing weight $(\mathrm{kg})$ by the height $\left(\mathrm{m}^{2}\right)$ for each woman. Also, the waist circumference was measured between the chest and hips with light clothing with an accuracy of $10 \mathrm{~cm}$ without any pressure on the pelvic range. The hip circumference was calculated using the same route with an elastic meter in the widest part of the hips [45].

\section{Physical activity}

Data about the level of physical activity was collected using the metabolic equivalents (MET)-based questionnaire, which its validity and reliability have been approved in Iran [46]. All of the results were presented as MET with 9 levels of activity from lowest activity such as rest and sleep (MET equal to 0.9) to intense activity such as jogging and basketball (MET more than 6). Women were classified into three categories of physical activity including low (MET less than 3), moderate (MET between 3 and 6 ), and severe (MET more than 6) [47]. Then the rate of daily energy expenditure of each woman was calculated based on their weight and MET-hour per day.

\section{Food security status}

The 18-item United States Department of Agriculture (USDA) food security questionnaire which has already been validated in Iran [48], was used to determine the status of household FI over the past 12 months. As presented in Table 1, the participants were stratified into two groups based on their scores 
from positive answers (score 1) or negative answers (score 0 ). In this regard, positive answers were considered as "often, sometimes, almost every month, some months, and yes" and negatives answers as "not correct, refused or did not know, only once or twice a month, and no". Also, the previous-related questions, which the participants have received a score of 0 , were not asked and were given a score of 0 . The maximum score of this questionnaire is 14 if both sections were completed [49].

\section{Dietary intakes}

Data on the dietary intakes of women was collected using a semi-quantitative food frequency questionnaire (FFQ) that was previously validated in Iran [50]. The FFQ consisted of 168 food groups with standard size units of foods and beverages that are commonly consumed in the dish of Iranian foods. Food items were categorized into 19 groups, according to their compositions for use in the analysis of the dietary patterns [51]. Based on the type of foods, participants reported their frequency of food intake as never, per day, week, month, and year over the past year before this study [52]. The case group especially was asked about their intake before the definite diagnosis of PCOS. Then all data on dietary assessments were converted to grams via Iranian household measures.

\section{Statistical analysis}

Quantitative variables via t-test method were presented as the mean ( \pm standard deviation; SD) and qualitative variables via chi-square method were presented as the number (percent) between two groups. All of the significant variables were entered into the multivariate logistic regression model and final independent variables were identified via the backward method after adjusted for confounders. The factor analysis model of main dietary components with the Varimax rotation was used for each of the classified food groups to determine the dietary patterns. Then main dietary patterns separately entered into the univariate logistic regression model. Finally, PCOS-related dietary patterns along with other significant variables (expect food security) in the univariate analysis models were separately entered into the multivariate logistic regression model with the forward method for determining the final independent risk factors and controlling the potential confounders. Statistical analyses were performed using the SPSS software (version 16), Nutritionist IV (First Databank, Hearst Corp., San Bruno, CA, USA), and Stata11SE software. $P$ values less than 0.05 were considered statistically significant.

\section{Results}

The frequency of PCOS symptoms including menstrual disorders was $90 \%(n=108)$, acne was $52.5 \%(n=$ $63)$, oily skin was $48.3 \%(n=58)$, hirsutism was $47.5 \%(n=57)$, and other symptoms was $0.8 \%(n=1)$ among case group.

Table 2 shows the food security status, anthropometry, and scio-economic factors of both case $(n=120)$ and control $(n=120)$ groups. The prevalence of food security was significantly lower in the case group than in the controls $(P<0.001)$. Approximately $60 \%$ of PCOS women $(n=67)$ had FI and near half of them 
$(n=32)$ experienced FI with hunger. While only $30 \%$ of the control group $(n=38)$ had FI and the majority of them $(n=24)$ had no hunger (Fig. 1).

According to Table 2, the case group had significantly higher menstrual age $(13.48 \pm 1.97$ vs. $12.82 \pm 1.43)$ and waist circumference $(100.65 \pm 12.04$ vs. $97.61 \pm 5.37)$ and lower economic level, rest or sleep MET-hour score $(1.32 \pm 0.99$ vs. $1.37 \pm 0.13)$, and the number of pregnancy, child, and family members compared to the controls $(P<0.05)$. There were no significant differences between ethnicity, weight, height, BMI, education level, the status of job, insurance support, and marriage, numbers of the employed person of household, hip circumference, and house ownership in PCOS and healthy women $(P>0.05)$.

Also in this study, two main healthy and quasi-western dietary patterns were defined (Fig. 2) and totally accounted for $24 \%$ of the whole variances that healthy dietary pattern had a higher rate than the quasiwestern dietary pattern. As shown in Table 3, the quasi-western dietary pattern including sugars, sweets, and desserts, industrial juice and soft drinks, processed meats, red and organ meats, refined grains, salt, French fries and potato chips, and tea and coffee had the highest factor loading, respectively. Solid oils and animal fat and also salt had a negative factor loading. The PCOS group had a significantly higher intake of sugars, sweets, and desserts $(28.47 \pm 4.50$ vs. $9.49 \pm 4.12)$, industrial juice and soft drinks ( $8.77 \pm 2.77$ vs. $4.77 \pm 3.12)$, processed meats $(15.85 \pm 4.26$ vs. $3.70 \pm 1.64)$, red and organ meats (17.62 \pm 2.84 vs. $10.40 \pm 2.47)$, salt $(4.90 \pm 1.77$ vs. $3.32 \pm 1.24)$, and tea and coffee $(21.24 \pm 3.20$ vs. $8.17 \pm 4.62)$ compared to the control group $(P<0.05)$.

On the other hand, healthy dietary pattern including fruits and vegetables, tomato, dairy products, fish and poultry, liquid oils, egg, legumes and soy, and nuts had the highest factor loading, respectively. According to Table 3 , the intake of fruits and vegetables $(232.91 \pm 13.33$ vs. $406.37 \pm 14.28)$, tomato $(36.33 \pm 7.99$ vs. $471.29 \pm 5.37)$, dairy products $(2.52 \pm 1.58$ vs. $5.69 \pm 1.17)$, fish and poultry $(24.81 \pm 5.83$ vs. $37.59 \pm 5.58)$, egg $(13.78 \pm 5.25$ vs. $22.66 \pm 5.61)$, legumes and soy $(171.72 \pm 12.53$ vs. $248.38 \pm 12.06)$, and nuts $(65.34 \pm 4.19$ vs. 79.05 \pm 6.41$)$ were significantly lower in the PCOS group compared to the controls $(P<0.05)$.

According to our data on the dietary intakes of micro and macronutrients, PCOS women had significantly higher food consumption and higher intake of saturated fats, monounsaturated fatty acids (MUFAs), oleic acid, fluorine, sucrose, and caffeine compared to the controls $(P<0.05)$. While non-PCOS women had a significantly higher intake of vitamins $A, B_{5}, B_{6}, B_{12}, C$, and $D$, potassium, proteins, carbohydrates, cholesterols, docosahexaenoic acid, potassium, beta- and alpha-carotene, lutein, beta-cryptoxanthin, lycopene, calcium, iron, thiamine, riboflavin, niacin, tetrahydrofolate, dihydrofolate, biotin, phosphorus, magnesium, zinc, copper, total, insoluble, and crude fiber, glucose, galactose, fructose, and lactose compared to the cases $(P<0.05)$. There were no significant differences between the intake of calories, trans fats, polyunsaturated fatty acids (PUFAs), linoleic acid, linolenic acid, eicosapentaenoic acid, sodium, vitamin E, alpha-tocopherol, manganese, selenium, chromium, soluble fiber, total sugar, and maltose between the study groups $(P>0.05)$. 
Tables 4 and 5 show odds ratios (ORs) and confidence intervals (Cls) for the association between important independent risk factors with PCOS. According to the final analysis model, after controlling the potential confounders, there were significant positive association between the risk of PCOS with FI (OR= 2.665, $\mathrm{Cl}=1.461-4.860)$, waist circumference $>97 \mathrm{~cm}(\mathrm{OR}=2.262,95 \% \mathrm{Cl}=1.301-3.933)$, and $\mathrm{MET}$ score $\leq$ 1.33 per hour $(\mathrm{OR}=2.165,95 \% \mathrm{Cl}=1.244-3.769)(\mathrm{P}<0.05$, Table 4$)$. According to the multivariate logistic regression model, the risk of PCOS was positively associated with the quasi-western dietary pattern (OR= $51.890,95 \% \mathrm{Cl}=18.140-148.43)$, low economic level $(\mathrm{OR}=6.886,95 \% \mathrm{Cl}=2.745-17.275)$, menstrual age $(\mathrm{OR}=1.409,95 \% \mathrm{Cl}=1.128-1.760)$, and waist circumference $(\mathrm{OR}=1.041,95 \% \mathrm{Cl}=1.001-1.082)$ and negatively associated with healthy dietary pattern $(\mathrm{OR}=0.140,95 \% \mathrm{Cl}=0.085-0.230)$ and $\mathrm{MET}$ score (OR= $0.008,95 \% \mathrm{Cl}=0.000-0.194)(\mathrm{P}<0.05$, table 5$)$.

\section{Discussion}

To our best knowledge, this is the first case-control study determining the association between food security status and dietary patterns with PCOS. The results demonstrated that FI especially with moderate to severe hunger was significantly higher among PCOS women than healthy non-PCOS women. Moreover, the risk of PCOS was positively associated with Fl, quasi-western dietary pattern, low economic level, waist circumference, and menstrual age and negatively associated with physical activity and healthy dietary pattern even after controlling the potential confounders.

According to our result, almost $60 \%$ of women with PCOS and $30 \%$ of non-PCOS women had FI. Around the world, FI especially in women is one of the most challenging can exert several adverse effects such as obesity [30,31, 53-55] and altering physical activity [56]. Furthermore, obesity itself which can be manifested as high waist circumference can amplify the severity of kinds of metabolic disorders such as PCOS [57-59]. Also, it is reported that physical activity is inversely associated with and PCOS [8, 60]. Therefore, it can be concluded that FI has a potential role to indirectly affect PCOS risk. Our results demonstrated that the risk of PCOS was positively associated with waist circumference and menstrual age and negatively associated with physical activity. However, some other studies have failed to find any significant association between PCOS with waist circumference, menstrual age [61], and physical activity $[36,61,62]$ in comparison to non-PCOS women.

Several studies demonstrated a positive association between low economic levels with $\mathrm{FI}[63,64]$ and PCOS $[8,32]$ in line with the present study. FI can induce persons to pay less cost for purchasing foods, consume smaller amounts of foods, change their dietary patterns [65-67], reduce the variety of dietary intakes, and increase the consumption of high-calorie foods [68]. A high-calorie diet itself can lead to hyperlipidemia, obesity, and T2DM [69-71].

According to the results of the current study, the quasi-western dietary pattern and healthy dietary pattern were associated with the increased and decreased risk of PCOS, respectively. This positive effect of quasi-western dietary pattern on the risk of PCOS can be due to the low rate of healthy foods including 
fruits and vegetables, and the high rate of unhealthy food items e.g. meats, industrial juice, French fries, and sweets [39] and excessive amounts of fats and sugar in this type of diet [72].

Saturated fatty acid as an undeniable component of the quasi-Western diet, is directly related to increased IR $[73,74]$ unlike omega-3 unsaturated fatty acid as a component of a healthy diet $[2,22]$. The results of the current study identified higher consumption of saturated fats and MUFAs and lower consumption of cholesterols and docosahexaenoic acid in women with PCOS. Numerous studies have shown that high dietary fat intake, particularly trans and saturated fats is associated with a higher risk of T2DM and CVD $[75,76]$ that can exert an adverse effect on the PCOS with increasing the inflammatory factors [77]. No significant differences were seen between the intake of calories, trans fats, PUFAs, linoleic acid, linolenic acid, and eicosapentaenoic acid in women with and without PCOS in our study. In a cohort study, Douglas et al. indicated that total, trans, and saturated fat, MUFAs, PUFAs, and cholesterol were not significantly different between the two groups [78]. However, other studies reported a higher intake of saturated fatty acids in PCOS women $[79,80]$. Moreover, meats have been related to obesity and inflammation due to their high-fat content [81]. But, they are suggested to be considered as healthy dishes of PCOS subjects due to their high content of iron [60]. Our result demonstrated that adult women with PCOS were more adhere to meat consumption. In contrast, Hajivandi et al. reported a low intake of meats in young PCOS women [60].

There are contradictory results on the association between high intake of protein with insulin and glucose responses [82, 83]. In the current study, the protein intake of PCOS women was lower; while, the proportion of unhealthy protein such as meats to healthy protein sources such as fish, poultry, legumes, and soy were higher in the women with PCOS than non-PCOS women. However, other studies did not report any differences among women with and without PCOS $[62,78]$. Based on a possible mechanism, animal proteins compared to vegetable proteins may increase the serum levels of insulin-like growth factor I (IGF-I) which can be involved in increasing the risk of PCOS [8].

It was found that high intake of fats and low intake of carbohydrates can be positively associated with weight, insulin and androgen concentrations, and the prevalence of PCOS [84]. The results of this study indicated that the total mean of carbohydrates was lower in women with PCOS compared to non-PCOS women. However, other studies failed to find any significant differences [62, 78]. On the other hand, our results demonstrated that the proportion intake of simple carbohydrates such as sugar and soft drinks to complex carbohydrates such as legumes was higher in the PCOS subjects. In line with our results, it was reported that PCOS women were more likely to have high GI foods and there is a positive association between this diet and IR [85]. In contrast, low GI foods appeared to have beneficial effects on IR improvement [86].

Several studies have demonstrated the inverse relationship between the healthy dietary intake which is rich in fruits and vegetables with visceral fat, weight, and the risk of T2DM and also the intake of dairy products with IR and dyslipidemia [87-89]. This study showed that the consumption of vegetables, fruits, and dairy products was lower in PCOS women. Fruits and vegetables are a major source of fiber, 
vitamins, and minerals that are associated with a lower prevalence of metabolic diseases [90]. It has been shown that fiber intake has been associated with a reduction of PCOS risk [80]. Moreover, dietary intake of dairy products exerts its beneficial effects on infertility and BMI by reducing the IR [91-93]. However, the effects of high-fat over low-fat dairies on PCOS are not clear [7]. Similar to the previous study [36, 61], PCOS women in the present study had lower consumption of dairy products than non-PCOS women. However, Shishehgar et al. found no significant differences between the dietary intake of dairies and fruits among the two groups [94].

The results of the present study reported that PCOS women had a lower intake of several kinds of vitamins such as $A, B_{5}, B_{6}, B_{12}, C$, and $D$, potassium, iron, zinc, thiamine, niacin, magnesium, phosphorus, and total fiber compared to non-PCOS women. It has been reported that adult women with FI were less likely to intake magnesium, vitamins $B_{6}$ and $E$, thiamine, and niacin [95]. Consistent with our finding, Moran et al. demonstrated a higher intake of magnesium, vitamins $A$ and $E$, phosphorus, and iron in PCOS women [96]. Moreover, Douglas et al. found no significant association in the magnesium intake of women with and without PCOS [78]. Epidemiological studies have shown that magnesium intake might decrease the risk of T2DM in PCOS women $[97,98]$ and dietary intake of sodium can exert an adverse effect on their blood pressure [99]. Calcium as one of the key minerals is suggested to be consumed by PCOS women due to its beneficial effects on IR, follicular maturation, and menstrual regulation [100]. Most studies have indicated the role of vitamin D and calcium in IR and insulin secretion [101, 102]. However, the exact molecular mechanisms of the effects of vitamin D on the improvement of IR and PCOS are not yet clear [103]. The possible role for folate and vitamin $B_{12}$ is decreasing the serum levels of homocysteine among PCOS women with IR $[104,105]$ and also for zinc is modifying the clinical and inflammatory biomarkers of PCOS women [11]. In our study, there were no differences between the rate of trans fats, PUFAs, eicosapentaenoic acid, sodium, vitamin E, alpha-tocopherol, manganese, selenium, and chromium among PCOS and non-PCOS women. However, Eslamian et al. positively demonstrated the association between fat, animal protein, carbohydrate, cholesterol, saturated fatty acid, sodium, biotin, iron, copper, fluoride, zinc, and calcium with the risk of PCOS [19].

Several major strengths are in the present study. First, this study investigated the association between FI and PCOS for the first time in Iran. Second, we compared characteristics of both PCOS and non-PCOS women due to the case-control design of our study. Third, we considered the non-smoking women and excluded those who had any current history of cardiovascular, liver, and/or kidney diseases which might affect the results. Last but not least, this study also assessed the association between PCOS with dietary patterns and food intakes. However, our study had some limitations. The sample was limited to overweight and obese women with specific ranges of age and BMI, who were referred to the infertility clinic of one hospital which makes it difficult to generalize the results to other women with other ages and BMI.

\section{Conclusion}


In general, this case-control study has shown that the risk of PCOS was positively associated with $\mathrm{Fl}$, quasi-western dietary pattern, waist circumference, menstrual age, and low economic status and negatively associated with the healthy dietary pattern and physical activity even after controlling the potential confounders. Further prospective studies including other ages and BMI are required to confirm our findings and increase our understanding of the associations between food security status and dietary patterns with PCOS.

\section{Abbreviations}

PCOS: Polycystic ovary syndrome, PCOM: Polycystic ovarian morphology, IR: Insulin resistance, T2DM: Type 2 diabetes, CVD: Cardiovascular disease, FI: Food insecurity, DASH: Dietary approaches to stop hypertension, BMI: body mass index, MD: Mediterranean diet, Gl: Glycemic index, $\mathrm{kg} / \mathrm{m}^{2}$ : kilogram per meter square, cm: centimeters, MET: Metabolic equivalents, USDA: United States Department of Agriculture, FFQ: Food frequency questionnaire, SD: Standard deviation, MUFAs: Monounsaturated fatty acids, PUFAs: Polyunsaturated fatty acids, ORs: Odds ratios, Cls: Confidence interval, IGF-I: Insulin-like growth factor I

\section{Declarations}

\section{Acknowledgments}

We appreciated all participated women and staff in the infertility clinic of Arash Hospital and also, the staff in the Ethics Committee of Tehran University of Medical Sciences in Tehran for their valuable contributions.

\section{Authors' contributions}

MBF, MDM, AM, KM, and AAN conceived and developed the presented idea. MBF, SEB, and MDM wrote numerous drafts. $\mathrm{MH}$ and MDM verified the analytical methods and contributed to statistical interpretations. AAN supervised the findings of this work. All authors discussed the results, contributed to the final manuscript, and reviewed, revised, read, and approved it.

\section{Funding}

There has been no funding for conducting, writing, and publishing of this article.

\section{Availability of data and materials}

All data supporting the results of our article will be made available from the corresponding author on reasonable request.

\section{Ethics approval and consent to participate}


The study was approved by the Ethics Committee of Tehran University of Medical Sciences, Tehran, Iran (Thesis Code: 9123323002). All stages of this research have been performed according to the Helsinki declaration. All procedures of the study were explained clearly to the participants who had the eligible inclusion criterion. Moreover, all participants voluntarily filled out the written informed consent form before they join the study and they were free to decide whether or not to attend or withdraw at any time and for any reason without changing the medical care.

\section{Consent for publication}

Not applicable.

\section{Conflict of interests}

No potential competing interests were declared by the authors.

\section{Author details}

${ }^{1}$ Department of Community Nutrition, School of Nutritional Sciences and Dietetics, Tehran University of Medical Sciences, Tehran, Iran. ${ }^{2}$ Department of Community Nutrition, School of Nutrition and Food Sciences, Isfahan University of Medical Sciences, Isfahan, Iran. ${ }^{3}$ Department of Community Nutrition, School of Nutritional Sciences and Dietetics, Tehran University of Medical Sciences, Tehran, Iran.

${ }^{4}$ Department of Obstetrics and Gynecology, School of Medicine, Tehran University of Medical Sciences, Tehran, Iran. ${ }^{5}$ Department of Biostatistics and Epidemiology, School of Public Health, Tehran University of Medical Sciences, Tehran, Iran. ${ }^{6}$ School of Paramedicine, Guilan University of Medical Sciences, Langroud, Iran. ${ }^{7}$ Department of Nutrition, School of Medicine, Jiroft University of Medical Sciences, Jiroft, Kerman, Iran.

\section{References}

1. Bykowska-Derda, A., et al., Diet quality scores in relation to fatness and nutritional knowledge in women with polycystic ovary syndrome: case-control study. Public Health Nutr, 2020: p. 1-10.

2. Faghfoori, Z., et al., Nutritional management in women with polycystic ovary syndrome: A review study. Diabetes Metab Syndr, 2017. 11 Suppl 1: p. S429-S432.

3. Shang, Y., et al., Effect of Diet on Insulin Resistance in Polycystic Ovary Syndrome. J Clin Endocrinol Metab, 2020. 105(10).

4. Fazelian, S., et al., Chromium supplementation and polycystic ovary syndrome: A systematic review and meta-analysis. J Trace Elem Med Biol, 2017. 42: p. 92-96.

5. Amirjani, S., et al., Dietary intake and lifestyle behaviour in different phenotypes of polycystic ovarian syndrome: a case-control study. J Hum Nutr Diet, 2019. 32(4): p. 413-421.

6. Copp, T., et al., Impact of a diagnosis of polycystic ovary syndrome on diet, physical activity and contraceptive use in young women: findings from the Australian Longitudinal Study of Women's 
Health. Hum Reprod, 2020. 35(2): p. 394-403.

7. Janiszewska, J., J. Ostrowska, and D. Szostak-Węgierek, Milk and Dairy Products and Their Impact on Carbohydrate Metabolism and Fertility-A Potential Role in the Diet of Women with Polycystic Ovary Syndrome. Nutrients, 2020. 12(11).

8. Shahdadian, F., et al., Association between major dietary patterns and polycystic ovary syndrome: evidence from a case-control study. Appl Physiol Nutr Metab, 2019. 44(1): p. 52-58.

9. Panjeshahin, A., et al., Association between empirically derived dietary patterns and polycystic ovary syndrome: A case-control study. Nutrition, 2020. 79-80: p. 110987.

10. Babapour, M., et al., Associations Between Serum Magnesium Concentrations and Polycystic Ovary Syndrome Status: a Systematic Review and Meta-analysis. Biol Trace Elem Res, 2021. 199(4): p. 1297-1305.

11. Neves, L.P.P., et al., Nutritional and dietary aspects in polycystic ovary syndrome: insights into the biology of nutritional interventions. Gynecol Endocrinol, 2020. 36(12): p. 1047-1050.

12. Kite, C., et al., Exercise, or exercise and diet for the management of polycystic ovary syndrome: a systematic review and meta-analysis. Syst Rev, 2019. 8(1): p. 51.

13. Abedini, M., et al., Zinc status and polycystic ovarian syndrome: A systematic review and metaanalysis. J Trace Elem Med Biol, 2019. 52: p. 216-221.

14. Jafari-Sfidvajani, S., et al., The effect of vitamin D supplementation in combination with low-calorie diet on anthropometric indices and androgen hormones in women with polycystic ovary syndrome: a double-blind, randomized, placebo-controlled trial. J Endocrinol Invest, 2018. 41(5): p. 597-607.

15. Paoli, A., et al., Effects of a ketogenic diet in overweight women with polycystic ovary syndrome. J Transl Med, 2020. 18(1): p. 104.

16. Muscogiuri, G., et al., Current Insights Into Inositol Isoforms, Mediterranean and Ketogenic Diets for Polycystic Ovary Syndrome: From Bench to Bedside. Curr Pharm Des, 2016. 22(36): p. 5554-5557.

17. Ganie, M.A., et al., Comparative Evaluation of Biomarkers of Inflammation Among Indian Women With Polycystic Ovary Syndrome (PCOS) Consuming Vegetarian vs. Non-vegetarian Diet. Front Endocrinol (Lausanne), 2019. 10: p. 699.

18. Foroozanfard, F., et al., The effects of dietary approaches to stop hypertension diet on weight loss, anti-Mullerian hormone and metabolic profiles in women with polycystic ovary syndrome: A randomized clinical trial. Clin Endocrinol (Oxf), 2017. 87(1): p. 51-58.

19. Eslamian, G. and A. Hekmatdoost, Nutrient Patterns and Risk of Polycystic Ovary Syndrome. J Reprod Infertil, 2019. 20(3): p. 161-168.

20. de Lima Nunes, R., et al., Lifestyle interventions and quality of life for women with polycystic ovary syndrome: A systematic review and meta-analysis protocol. Medicine (Baltimore), 2019. 98(50): p. e18323.

21. Zhang, X., et al., The Effect of Low Carbohydrate Diet on Polycystic Ovary Syndrome: A MetaAnalysis of Randomized Controlled Trials. Int J Endocrinol, 2019. 2019: p. 4386401. 
22. Wang, T., et al., Dietary a-Linolenic Acid-Rich Flaxseed Oil Exerts Beneficial Effects on Polycystic Ovary Syndrome Through Sex Steroid Hormones-Microbiota-Inflammation Axis in Rats. Front Endocrinol (Lausanne), 2020. 11: p. 284.

23. Kim, C.H., S.J. Chon, and S.H. Lee, Effects of lifestyle modification in polycystic ovary syndrome compared to metformin only or metformin addition: A systematic review and meta-analysis. Sci Rep, 2020. 10(1): p. 7802.

24. Szczuko, M., et al., Quantitative assessment of nutrition in patients with polycystic ovary syndrome (PCOS). Rocz Panstw Zakl Hig, 2016. 67(4): p. 419-426.

25. Shishehgar, F., et al., Does a restricted energy low glycemic index diet have a different effect on overweight women with or without polycystic ovary syndrome? BMC Endocr Disord, 2019. 19(1): p. 93.

26. Nadjarzadeh, A., et al., Effect of hypocaloric high-protein, low-carbohydrate diet supplemented with fennel on androgenic and anthropometric indices in overweight and obese women with polycystic ovary syndrome: A randomized placebo-controlled trial. Complement Ther Med, 2021. 56: p. 102633.

27. Foley, E. and C. Marsh, Polycystic ovary syndrome: is a Western diet sabotaging our best efforts at management? Fertil Steril, 2019. 112(4): p. 653-654.

28. Ramos-Lopez, O., et al., Guide for Current Nutrigenetic, Nutrigenomic, and Nutriepigenetic Approaches for Precision Nutrition Involving the Prevention and Management of Chronic Diseases Associated with Obesity. J Nutrigenet Nutrigenomics, 2017. 10(1-2): p. 43-62.

29. Cunha, N.B.D., et al., Dietary intake, body composition and metabolic parameters in women with polycystic ovary syndrome. Clin Nutr, 2019. 38(5): p. 2342-2348.

30. Moradi, S., et al., Food insecurity and the risk of undernutrition complications among children and adolescents: A systematic review and meta-analysis. Nutrition, 2019. 62: p. 52-60.

31. Tamargo, J.A., et al., Food insecurity is associated with magnetic resonance-determined nonalcoholic fatty liver and liver fibrosis in low-income, middle-aged adults with and without HIV. Am J Clin Nutr, 2021. 113(3): p. 593-601.

32. Badri Fariman, M., et al., Food Security and Some Associated Factors among Women with PolyCystic Ovary Syndrome. World Essays J, 2016. 4(1): p. 35-9.

33. Pourmotabbed, A., et al., Food insecurity and mental health: a systematic review and meta-analysis. Public Health Nutr, 2020. 23(10): p. 1778-1790.

34. Behzadifar, M., et al., Prevalence of Food Insecurity in Iran: A Systematic Review and Meta-analysis. Arch Iran Med, 2016. 19(4): p. 288-94.

35. Daneshi-Maskooni, M., et al., Questionnaire-based Prevalence of Food Insecurity in Iran: A Review Article. Iran J Public Health, 2017. 46(11): p. 1454-1464.

36. Hosseini, M.S., et al., Healthy eating index in women with polycystic ovary syndrome: A case-control study. Int J Reprod Biomed, 2017. 15(9): p. 575-582. 
37. Karamali, M., et al., The effect of dietary soy intake on weight loss, glycaemic control, lipid profiles and biomarkers of inflammation and oxidative stress in women with polycystic ovary syndrome: a randomised clinical trial. J Hum Nutr Diet, 2018. 31(4): p. 533-543.

38. Azadi-Yazdi, M., et al., Effects of Dietary Approach to Stop Hypertension diet on androgens, antioxidant status and body composition in overweight and obese women with polycystic ovary syndrome: a randomised controlled trial. J Hum Nutr Diet, 2017. 30(3): p. 275-283.

39. Barrea, L., et al., Adherence to the Mediterranean Diet, Dietary Patterns and Body Composition in Women with Polycystic Ovary Syndrome (PCOS). Nutrients, 2019. 11(10).

40. De Giuseppe, R., et al., Dietary underreporting in women affected by polycystic ovary syndrome: A pilot study. Nutr Diet, 2019. 76(5): p. 560-566.

41. Altieri, P., et al., Dietary habits and their relationship with hormones and metabolism in overweight and obese women with polycystic ovary syndrome. Clin Endocrinol (Oxf), 2013. 78(1): p. 52-9.

42. Farsinejad-Marj, M., et al., Clinical and Metabolic Responses to Magnesium Supplementation in Women with Polycystic Ovary Syndrome. Biol Trace Elem Res, 2020. 196(2): p. 349-358.

43. Cutler, D.A., S.M. Pride, and A.P. Cheung, Low intakes of dietary fiber and magnesium are associated with insulin resistance and hyperandrogenism in polycystic ovary syndrome: A cohort study. Food Sci Nutr, 2019. 7(4): p. 1426-1437.

44. Revised 2003 consensus on diagnostic criteria and long-term health risks related to polycystic ovary syndrome (PCOS). Hum Reprod, 2004. 19(1): p. 41-7.

45. Lashkardoost, H., et al., Hypertension and its Relation with Waist to Hip Ratio in Women Referred to Bojnurd Urban Health Centers in 2014. The Open Hypertension Journal, 2019. 11(1).

46. Momenan, A.A., et al., Reliability and validity of the Modifiable Activity Questionnaire (MAQ) in an Iranian urban adult population. Arch Iran Med, 2012. 15(5): p. 279-82.

47. Aadahl, M., M. Kjaer, and T. Jørgensen, Associations between overall physical activity level and cardiovascular risk factors in an adult population. Eur J Epidemiol, 2007. 22(6): p. 369-78.

48. Ramesh, T., A. Dorosty Motlagh, and M. Abdollahi, Prevalence of household food insecurity in the City of Shiraz and its association with socio-economic and demographic factors, 2008. Iranian journal of nutrition sciences \& food technology, 2010. 4(4): p. 53-64.

49. Bickel, G., et al., Guide to measuring household food security. 2000, Revised.

50. Mirmiran, P., et al., Reliability and relative validity of an FFQ for nutrients in the Tehran lipid and glucose study. Public Health Nutr, 2010. 13(5): p. 654-62.

51. Karimi, Z., et al., Dietary patterns and breast cancer risk among women. Public Health Nutrition, 2014. 17(5): p. 1098-1106.

52. Vahid, F., et al., Association Between Index of Nutritional Quality and Nonalcoholic Fatty Liver Disease: The Role of Vitamin D and B Group. Am J Med Sci, 2019. 358(3): p. 212-218.

53. Pourmotabbed, A., et al., The Relationship between Food Insecurity and Risk of Overweight or Obesity in under 18 Years Individuals: A Systematic Review and Meta-Analysis. Int J Prev Med, 2020. 11: p. 
158.

54. Moradi, S., et al., Food insecurity and adult weight abnormality risk: a systematic review and metaanalysis. Eur J Nutr, 2019. 58(1): p. 45-61.

55. Seligman, H.K., et al., Food insecurity is associated with hypoglycemia and poor diabetes selfmanagement in a low-income sample with diabetes. J Health Care Poor Underserved, 2010. 21(4): p. 1227-33.

56. Fram, M.S., et al., Child experience of food insecurity is associated with child diet and physical activity. J Nutr, 2015. 145(3): p. 499-504.

57. Li, L., et al., Metabolic effect of obesity on polycystic ovary syndrome in adolescents: a metaanalysis. J Obstet Gynaecol, 2017. 37(8): p. 1036-1047.

58. Glueck, C.J. and N. Goldenberg, Characteristics of obesity in polycystic ovary syndrome: Etiology, treatment, and genetics. Metabolism, 2019. 92: p. 108-120.

59. Barber, T.M., et al., Obesity and Polycystic Ovary Syndrome: Implications for Pathogenesis and Novel Management Strategies. Clin Med Insights Reprod Health, 2019. 13: p. 1179558119874042.

60. Hajivandi, L., et al., Food habits in overweight and obese adolescent girls with Polycystic ovary syndrome (PCOS): a qualitative study in Iran. BMC Pediatr, 2020. 20(1): p. 277.

61. Rajaeieh, G., et al., The Relationship between Intake of Dairy Products and Polycystic Ovary Syndrome in Women Who Referred to Isfahan University of Medical Science Clinics in 2013. Int J Prev Med, 2014. 5(6): p. 687-94.

62. Ahmadi, A., et al., Anthropometric characteristics and dietary pattern of women with polycystic ovary syndrome. Indian J Endocrinol Metab, 2013. 17(4): p. 672-6.

63. Shim, J.E., et al., Spatial disparity in food environment and household economic resources related to food insecurity in rural Korean households with older adults. Nutrients, 2018. 10(10).

64. Asadi-Lari, M., et al., Socio-economic risk factors of household food insecurity and their population attributable risk: A population-based study. Med J Islam Repub Iran, 2019. 33: p. 119.

65. Kendall, A., C.M. Olson, and E.A. Frongillo, Jr., Relationship of hunger and food insecurity to food availability and consumption. J Am Diet Assoc, 1996. 96(10): p. 1019-24; quiz 1025-6.

66. Olson, C.M., Nutrition and health outcomes associated with food insecurity and hunger. J Nutr, 1999. 129(2S Suppl): p. 521s-524s.

67. Tarasuk, V.S. and G.H. Beaton, Women's dietary intakes in the context of household food insecurity. J Nutr, 1999. 129(3): p. 672-9.

68. Monsivais, P. and A. Drewnowski, The rising cost of low-energy-density foods. J Am Diet Assoc, 2007. 107(12): p. 2071-6.

69. Riobó Serván, P., [Diet recomendations in diabetes and obesity]. Nutr Hosp, 2018. 35(Spec No4): p. 109-115.

70. Patel, T.P., et al., Insulin resistance: an additional risk factor in the pathogenesis of cardiovascular disease in type 2 diabetes. Heart Failure Reviews, 2016. 21(1): p. 11-23. 
71. Vozoris, N.T. and V.S. Tarasuk, Household food insufficiency is associated with poorer health. J Nutr, 2003. 133(1): p. 120-6.

72. Rakhra, V., et al., Obesity and the Western Diet: How We Got Here. Mo Med, 2020. 117(6): p. 536-538.

73. Esmaillzadeh, A., et al., Dietary patterns, insulin resistance, and prevalence of the metabolic syndrome in women. Am J Clin Nutr, 2007. 85(3): p. 910-8.

74. Isharwal, S., et al., Diet \& insulin resistance: a review \& Asian Indian perspective. Indian J Med Res, 2009. 129(5): p. 485-99.

75. Parker, D.R., et al., Relationship of dietary saturated fatty acids and body habitus to serum insulin concentrations: the Normative Aging Study. Am J Clin Nutr, 1993. 58(2): p. 129-36.

76. Stender, S. and J. Dyerberg, Influence of trans fatty acids on health. Ann Nutr Metab, 2004. 48(2): p. 61-6.

77. Delitala, A.P., et al., Polycystic ovary syndrome, adipose tissue and metabolic syndrome. Arch Gynecol Obstet, 2017. 296(3): p. 405-419.

78. Douglas, C.C., et al., Difference in dietary intake between women with polycystic ovary syndrome and healthy controls. Fertil Steril, 2006. 86(2): p. 411-7.

79. Carmina, E., et al., Difference in body weight between American and Italian women with polycystic ovary syndrome: influence of the diet. Hum Reprod, 2003. 18(11): p. 2289-93.

80. Wild, R.A., et al., Lipoprotein lipid concentrations and cardiovascular risk in women with polycystic ovary syndrome. J Clin Endocrinol Metab, 1985. 61(5): p. 946-51.

81. Chai, W., et al., Dietary Red and Processed Meat Intake and Markers of Adiposity and Inflammation: The Multiethnic Cohort Study. J Am Coll Nutr, 2017. 36(5): p. 378-385.

82. Farnsworth, E., et al., Effect of a high-protein, energy-restricted diet on body composition, glycemic control, and lipid concentrations in overweight and obese hyperinsulinemic men and women. Am J Clin Nutr, 2003. 78(1): p. 31-9.

83. Gannon, M.C., et al., An increase in dietary protein improves the blood glucose response in persons with type 2 diabetes. Am J Clin Nutr, 2003. 78(4): p. 734-41.

84. Mavropoulos, J.C., et al., The effects of a low-carbohydrate, ketogenic diet on the polycystic ovary syndrome: A pilot study. Nutrition \& Metabolism, 2005. 2(1): p. 35.

85. Graff, S.K., et al., Dietary glycemic index is associated with less favorable anthropometric and metabolic profiles in polycystic ovary syndrome women with different phenotypes. Fertil Steril, 2013. 100(4): p. 1081-8.

86. Ebbeling, C.B., et al., Effects of an ad libitum low-glycemic load diet on cardiovascular disease risk factors in obese young adults. Am J Clin Nutr, 2005. 81(5): p. 976-82.

87. Cook, L.T., et al., Vegetable consumption is linked to decreased visceral and liver fat and improved insulin resistance in overweight Latino youth. J Acad Nutr Diet, 2014. 114(11): p. 1776-83.

88. Mozaffarian, D., et al., Trans-palmitoleic acid, metabolic risk factors, and new-onset diabetes in U.S. adults: a cohort study. Ann Intern Med, 2010. 153(12): p. 790-9. 
89. Schulze, M.B., et al., Dietary pattern, inflammation, and incidence of type 2 diabetes in women. Am J Clin Nutr, 2005. 82(3): p. 675-84; quiz 714-5.

90. Paknahad, Z. and H. Zeraei-Bidgoli, Metabolic syndrome and nonalcoholic fatty liver disease: Nutritional approach for prevention. Journal of Isfahan Medical School, 2013. 31(252): p. 14611480.

91. Akter, S., et al., Dairy consumption is associated with decreased insulin resistance among the Japanese. Nutr Res, 2013. 33(4): p. 286-92.

92. Greenlee, A.R., T.E. Arbuckle, and P.H. Chyou, Risk factors for female infertility in an agricultural region. Epidemiology, 2003. 14(4): p. 429-36.

93. Zemel, M.B., Role of calcium and dairy products in energy partitioning and weight management. Am J Clin Nutr, 2004. 79(5): p. 907s-912s.

94. Shishehgar, F., et al., Comparison of Dietary Intake between Polycystic Ovary Syndrome Women and Controls. Glob J Health Sci, 2016. 8(9): p. 54801.

95. Olson, C., Food Insecurity in Women: A Recipe for Unhealthy Trade-offs. Topics in Clinical Nutrition, 2005. 20: p. 321-328.

96. Moran, L.J., et al., The contribution of diet, physical activity and sedentary behaviour to body mass index in women with and without polycystic ovary syndrome. Hum Reprod, 2013. 28(8): p. 2276-83.

97. Colditz, G.A., et al., Diet and risk of clinical diabetes in women. Am J Clin Nutr, 1992. 55(5): p. 101823.

98. Salmerón, J., et al., Dietary fat intake and risk of type 2 diabetes in women. Am J Clin Nutr, 2001. 73(6): p. 1019-26.

99. Espeland, M.A., et al., Predictors and mediators of successful long-term withdrawal from antihypertensive medications. Archives of family medicine, 1999. 8(3): p. 228.

100. Szczuko, M., et al., Quantitative assessment of nutrition in patients with polycystic ovary syndrome (PCOS). Roczniki Państwowego Zakładu Higieny, 2016. 67(4).

101. Billaudel, B.J., et al., Regulatory effect of 1,25-dihydroxyvitamin D3 on insulin release and calcium handling via the phospholipid pathway in islets from vitamin D-deficient rats. J Endocrinol Invest, 1995. 18(9): p. 673-82.

102. Ortlepp, J.R., et al., The vitamin D receptor gene variant and physical activity predicts fasting glucose levels in healthy young men. Diabet Med, 2003. 20(6): p. 451-4.

103. Lajtai, K., et al., Effects of Vitamin D Deficiency on Proliferation and Autophagy of Ovarian and Liver Tissues in a Rat Model of Polycystic Ovary Syndrome. Biomolecules, 2019. 9(9).

104. McCarty, M.F., Insulin secretion as a potential determinant of homocysteine levels. Med Hypotheses, 2000. 55(5): p. 454-5.

105. Setola, E., et al., Insulin resistance and endothelial function are improved after folate and vitamin B12 therapy in patients with metabolic syndrome: relationship between homocysteine levels and hyperinsulinemia. Eur J Endocrinol, 2004. 151(4): p. 483-9. 


\section{Tables}

Table 1 The status of household food security according to USDA FI questionnaire

\begin{tabular}{|c|c|c|c|c|c|}
\hline & & & Code & $\begin{array}{l}\text { With children< } \\
18-y^{*}\end{array}$ & $\begin{array}{l}\text { Without children< } \\
18-y^{\star *}\end{array}$ \\
\hline \multirow{4}{*}{$\begin{array}{l}\text { Household food security } \\
\text { status }\end{array}$} & \multicolumn{2}{|l|}{ Secure } & 0 & $0-2$ & $0-2$ \\
\hline & \multirow[t]{3}{*}{ Insecure } & $\begin{array}{l}\text { Without } \\
\text { hunger }\end{array}$ & 1 & $3-7$ & $3-5$ \\
\hline & & $\begin{array}{l}\text { Moderate } \\
\text { hunger }\end{array}$ & 2 & $8-12$ & $6-8$ \\
\hline & & $\begin{array}{l}\text { Severe } \\
\text { hunger }\end{array}$ & 3 & $13-18$ & $9-10$ \\
\hline
\end{tabular}

*Number of positive answers out of 18 scores.

${ }^{* *}$ Number of positive answers out of 10 scores. 
Table 2

Characteristics of the participants according to the T-test and chi-square test

\begin{tabular}{|c|c|c|c|c|c|}
\hline & & & $\begin{array}{l}\text { Cases }(n= \\
120)\end{array}$ & $\begin{array}{l}\text { Controls }(n \\
=120)\end{array}$ & $\begin{array}{l}P \\
\text { value }\end{array}$ \\
\hline \multirow[t]{4}{*}{ Food security } & \multicolumn{2}{|l|}{ Secure } & $53(44.2 \%)$ & $82(68.3 \%)$ & \multirow{4}{*}{$\begin{array}{l}< \\
0.001\end{array}$} \\
\hline & \multirow[t]{3}{*}{ Insecure } & $\begin{array}{l}\text { Without } \\
\text { hunger }\end{array}$ & 35 (29.2\%) & $24(20 \%)$ & \\
\hline & & $\begin{array}{l}\text { Moderate } \\
\text { hunger }\end{array}$ & 29 (24.2\%) & $13(10.8 \%)$ & \\
\hline & & Severe hunger & $3(2.5 \%)$ & $1(0.8 \%)$ & \\
\hline \multirow[t]{3}{*}{ Ethnicity } & Fars & & $58(48.3 \%)$ & 47 (39.2\%) & \multirow[t]{3}{*}{0.12} \\
\hline & Turk & & 35 (29.2\%) & $50(41.7 \%)$ & \\
\hline & Others & & 27 (27.5\%) & $23(19.2 \%)$ & \\
\hline Weight (kg) & & & $\begin{array}{l}76.83( \pm \\
10.89)\end{array}$ & $\begin{array}{l}74.75( \pm \\
8.12)\end{array}$ & 0.096 \\
\hline Height (cm) & & & $\begin{array}{l}161.16( \pm \\
5.56)\end{array}$ & $\begin{array}{l}160.70( \pm \\
7.03)\end{array}$ & 0.57 \\
\hline BMI $\left(\mathrm{kg} / \mathrm{m}^{2}\right)$ & & & $\begin{array}{l}29.55( \pm \\
3.70)\end{array}$ & $\begin{array}{l}28.88( \pm \\
1.74)\end{array}$ & 0.076 \\
\hline \multirow[t]{2}{*}{ Education level } & \multicolumn{2}{|c|}{ Under diploma } & 67 (55.8\%) & $65(54.2 \%)$ & \multirow[t]{2}{*}{0.79} \\
\hline & \multicolumn{2}{|c|}{ Diploma and higher } & $53(44.2 \%)$ & $55(45.8 \%)$ & \\
\hline \multirow[t]{2}{*}{ Economic level } & Upper mic & Ile to high & 78 (65\%) & 99 (82.5\%) & \multirow[t]{2}{*}{0.002} \\
\hline & Lower mi & dle to poor & 42 (35\%) & $21(17.5 \%)$ & \\
\hline \multirow[t]{3}{*}{ Job status } & Unemplos & & $80(66.7 \%)$ & $80(66.7 \%)$ & \multirow[t]{3}{*}{0.79} \\
\hline & Free, worl & r, or other & 20 (16.7\%) & $23(19.2 \%)$ & \\
\hline & Employe & & $20(16.7 \%)$ & $17(14.2 \%)$ & \\
\hline \multirow{2}{*}{$\begin{array}{l}\text { Numbers of employed persons } \\
\text { of household }\end{array}$} & 1 & & 86 (71.7\%) & 86 (77.7\%) & \multirow[t]{2}{*}{0.78} \\
\hline & $\geq 2$ & & $34(28.3 \%)$ & 34 (28.3\%) & \\
\hline \multirow[t]{2}{*}{ Marital status } & Unmarrie & or others & $17(14.2 \%)$ & $19(15.8 \%)$ & \multirow[t]{2}{*}{0.71} \\
\hline & Married & & $\begin{array}{l}103 \\
(85.8 \%)\end{array}$ & 101 (84.2\%) & \\
\hline
\end{tabular}

Data are mean $( \pm S D)$ for quantitative variables and number $(\%)$ for categorical variables MET Metabolic equivalents, $B M /$ Body mass index, $\mathrm{kg}$ kilogram, $\mathrm{cm}$ centimeter 


\begin{tabular}{|c|c|c|c|c|}
\hline & & $\begin{array}{l}\text { Cases }(n= \\
120)\end{array}$ & $\begin{array}{l}\text { Controls }(n \\
=120)\end{array}$ & $\begin{array}{l}\mathrm{P} \\
\text { value }\end{array}$ \\
\hline \multirow[t]{2}{*}{ Number of pregnancy } & 0 & $71(59.2 \%)$ & $52(43.3 \%)$ & \multirow[t]{2}{*}{0.002} \\
\hline & $\geq 1$ & $49(40.8 \%)$ & $68(56.7 \%)$ & \\
\hline \multirow[t]{2}{*}{ Number of children } & 0 & $88(73.3)$ & $59(49.2 \%)$ & \multirow{2}{*}{$\begin{array}{l}<.001 \\
0.001\end{array}$} \\
\hline & $\geq 1$ & $32(26.7 \%)$ & $61(50.8 \%)$ & \\
\hline \multicolumn{2}{|l|}{ Menstrual age (year) } & $\begin{array}{l}13.48( \pm \\
1.97)\end{array}$ & $\begin{array}{l}12.82( \pm \\
1.43)\end{array}$ & 0.003 \\
\hline \multicolumn{2}{|l|}{ Waist circumference } & $\begin{array}{l}100.65( \pm \\
12.04)\end{array}$ & $\begin{array}{l}97.61( \pm \\
5.37)\end{array}$ & 0.013 \\
\hline \multicolumn{2}{|l|}{ Hip circumference } & $\begin{array}{l}117.22( \pm \\
12.04)\end{array}$ & $\begin{array}{l}118.25( \pm \\
5.15)\end{array}$ & 0.39 \\
\hline \multicolumn{2}{|l|}{ Score of rest or sleep (MET-hour) } & $\begin{array}{l}1.32( \pm \\
0.99)\end{array}$ & $\begin{array}{l}1.37( \pm \\
0.13)\end{array}$ & $\begin{array}{l}< \\
0.001\end{array}$ \\
\hline \multirow[t]{2}{*}{ Numbers of family members } & $\leq 2$ & $68(56.7 \%)$ & $39(32.5 \%)$ & \multirow{2}{*}{$\begin{array}{l}< \\
0.001\end{array}$} \\
\hline & $\geq 3$ & $52(43.3 \%)$ & $81(67.5 \%)$ & \\
\hline \multirow[t]{2}{*}{ House ownership } & Personal or free & $41(34.2 \%)$ & $55(45.8 \%)$ & \multirow[t]{2}{*}{0.065} \\
\hline & Rental or pawn & $79(65.8 \%)$ & $65(54.2 \%)$ & \\
\hline \multirow[t]{3}{*}{ Insurance support status } & $\begin{array}{l}\text { Medical services (Health } \\
\text { Insurance) }\end{array}$ & $18(15 \%)$ & $33(27.5 \%)$ & \multirow[t]{3}{*}{0.055} \\
\hline & $\begin{array}{l}\text { Social security } \\
\text { organization }\end{array}$ & $77(64.2 \%)$ & $68(56.7 \%)$ & \\
\hline & other & $25(20.8 \%)$ & $19(15.8 \%)$ & \\
\hline \multicolumn{5}{|c|}{ Data are mean $( \pm S D)$ for quantitative variables and number $(\%)$ for categorical variables } \\
\hline \multicolumn{5}{|c|}{ MET Metabolic equivalents, $B M /$ Body mass index, $\mathrm{kg}$ kilogram, $\mathrm{cm}$ centimeter } \\
\hline
\end{tabular}


Table 3

Dietary patterns based on the T-test and factor loading matrix of two main dietary patterns with the Varimax rotation

\begin{tabular}{|c|c|c|c|c|c|c|}
\hline \multirow{2}{*}{$\begin{array}{l}\text { Food } \\
\text { groups }\end{array}$} & \multirow[t]{2}{*}{ Major food items in Iran } & \multicolumn{2}{|c|}{ Dietary patterns ${ }^{*}$} & \multirow{2}{*}{$\begin{array}{l}\text { Cases } \\
(n= \\
120)\end{array}$} & \multirow{2}{*}{$\begin{array}{l}\text { Controls } \\
(n= \\
120)\end{array}$} & \multirow{2}{*}{$\begin{array}{l}P \\
\text { value }\end{array}$} \\
\hline & & $\begin{array}{l}\text { Pattern } \\
1: \\
\text { healthy }\end{array}$ & $\begin{array}{l}\text { Pattern } \\
\text { 2: } \\
\text { quasi- } \\
\text { western }\end{array}$ & & & \\
\hline $\begin{array}{l}\text { Processed } \\
\text { meats }\end{array}$ & Sausage, kielbasa, hamburger & - & 0.465 & $\begin{array}{l}15.85 \\
( \pm 4.26)\end{array}$ & $\begin{array}{l}3.70( \pm \\
1.64)\end{array}$ & $\begin{array}{l}<.001 \\
0.00\end{array}$ \\
\hline $\begin{array}{l}\text { Red and } \\
\text { organ } \\
\text { meats }\end{array}$ & $\begin{array}{l}\text { Beef and veal, mutton, minced } \\
\text { meat, heart, liver, and offal, by- } \\
\text { products and abomasum, kale } \\
\text { pache, tongue, brain }\end{array}$ & - & 0.456 & $\begin{array}{l}17.62 \\
( \pm 2.84)\end{array}$ & $\begin{array}{l}10.40 \\
( \pm 2.47)\end{array}$ & $\begin{array}{l}<.001 \\
0 .\end{array}$ \\
\hline $\begin{array}{l}\text { Fish and } \\
\text { Poultry }\end{array}$ & Types of fish, tuna, chicken & 0.556 & - & $\begin{array}{l}24.81 \\
( \pm 5.83)\end{array}$ & $\begin{array}{l}37.59 \\
( \pm 5.58)\end{array}$ & $\begin{array}{l}< \\
0.001\end{array}$ \\
\hline Egg & Egg & 0.465 & - & $\begin{array}{l}13.78 \\
( \pm 5.25)\end{array}$ & $\begin{array}{l}22.66 \\
( \pm 5.61)\end{array}$ & $\begin{array}{l}<.001 \\
0.01\end{array}$ \\
\hline $\begin{array}{l}\text { Dairy } \\
\text { products }\end{array}$ & $\begin{array}{l}\text { Types of milk (low, normal, or } \\
\text { high fat), yogurt (low, normal, or } \\
\text { high fat), creamy or dripped } \\
\text { yogurt, dough, chocolate milk, } \\
\text { cheese (creamy or normal), } \\
\text { types of ice cream, curd, cream, } \\
\text { butterfat }\end{array}$ & 0.595 & - & $\begin{array}{l}2.52 \\
1.58)\end{array}( \pm$ & $\begin{array}{l}5.69\left(^{( \pm}\right. \\
1.17)^{(1)}\end{array}$ & $\begin{array}{l}<.001 \\
0.01\end{array}$ \\
\hline $\begin{array}{l}\text { Tea and } \\
\text { coffee }\end{array}$ & Tea and coffee & - & 0.319 & $\begin{array}{l}21.24 \\
( \pm 3.20)\end{array}$ & $\begin{array}{l}8.17( \pm \\
4.62)\end{array}$ & $\hat{0}_{0.001}$ \\
\hline $\begin{array}{l}\text { Fruits and } \\
\text { vegetables }\end{array}$ & $\begin{array}{l}\text { Cantaloupe and watermelon, } \\
\text { melon, watermelon, pear, apricot, } \\
\text { cherry and sour cherry, apple, } \\
\text { peach, nectarine, green tomato, } \\
\text { grape, kiwi, grapefruit, orange, } \\
\text { persimmon, tangerine, } \\
\text { pomegranate, yellow or red } \\
\text { plum, strawberry, banana, } \\
\text { lemonade, lemongrass, raisins, } \\
\text { fresh berries, fresh figs, } \\
\text { compotes, dried figs, dates, dried } \\
\text { berries, peach and apricot } \\
\text { leaves, natural juices, other fruits }\end{array}$ & 0.797 & - & $\begin{array}{l}232.91 \\
( \pm \\
13.33)\end{array}$ & $\begin{array}{l}406.37 \\
( \pm \\
14.28)\end{array}$ & $\begin{array}{l}<.001 \\
0.00\end{array}$ \\
\hline
\end{tabular}

All data are mean $( \pm S D)$ for quantitative variables

${ }^{*}$ Factor loadings $<0.30$ were not listed in the table for simplicity. 


\begin{tabular}{|c|c|c|c|c|c|c|}
\hline \multirow{2}{*}{$\begin{array}{l}\text { Food } \\
\text { groups }\end{array}$} & \multirow[t]{2}{*}{ Major food items in Iran } & \multicolumn{2}{|c|}{ Dietary patterns ${ }^{*}$} & \multirow{2}{*}{$\begin{array}{l}\text { Cases } \\
(n= \\
120)\end{array}$} & \multirow{2}{*}{$\begin{array}{l}\text { Controls } \\
(n= \\
120)\end{array}$} & \multirow{2}{*}{$\begin{array}{l}\mathrm{P} \\
\text { value }\end{array}$} \\
\hline & & $\begin{array}{l}\text { Pattern } \\
\text { 1: } \\
\text { healthy }\end{array}$ & $\begin{array}{l}\text { Pattern } \\
2 \text { : } \\
\text { quasi- } \\
\text { western }\end{array}$ & & & \\
\hline & $\begin{array}{l}\text { Lettuce, cucumber, stewed } \\
\text { vegetables, eggplant, celery, } \\
\text { green peas, green beans, green } \\
\text { peppers, bell peppers, turnips, } \\
\text { squash, pumpkin stew, } \\
\text { mushrooms, raw or fried onions, } \\
\text { boiled potatoes, garlic, Spinach, } \\
\text { raw or cooked carrots, other } \\
\text { vegetables }\end{array}$ & & & & & \\
\hline $\begin{array}{l}\text { Industrial } \\
\text { juice and } \\
\text { soft drinks }\end{array}$ & $\begin{array}{l}\text { Industrial juice, lemon juice, } \\
\text { types of drinks (soft drinks, } \\
\text { water poetry, industrial syrups) }\end{array}$ & - & 0.714 & $\begin{array}{l}8.77( \pm \\
2.77)\end{array}$ & $\begin{array}{l}4.77( \pm \\
3.12)\end{array}$ & $\begin{array}{l}< \\
0.001\end{array}$ \\
\hline $\begin{array}{l}\text { Legumes } \\
\text { and soy }\end{array}$ & $\begin{array}{l}\text { Beans, lentils, chickpeas, } \\
\text { cotyledon, broad bean, mung } \\
\text { bean and other legumes, } \\
\text { soybean meal }\end{array}$ & 0.429 & - & $\begin{array}{l}171.72 \\
( \pm \\
12.53)\end{array}$ & $\begin{array}{l}248.38 \\
( \pm \\
12.06)\end{array}$ & $\begin{array}{l}< \\
0.001\end{array}$ \\
\hline Nuts & $\begin{array}{l}\text { Peanuts, almonds, walnuts, } \\
\text { pistachios, hazelnuts, any kind } \\
\text { of seed }\end{array}$ & 0.351 & - & $\begin{array}{l}65.34 \\
( \pm 4.19)\end{array}$ & $\begin{array}{l}79.05 \\
( \pm 6.41)\end{array}$ & 0.042 \\
\hline $\begin{array}{l}\text { Whole } \\
\text { grains }\end{array}$ & $\begin{array}{l}\text { Sangak bread, taftoon, barbari, } \\
\text { barley bread, barley, wheat, } \\
\text { oatmeal, corn }\end{array}$ & - & - & $\begin{array}{l}1228.03 \\
( \pm \\
57.18)\end{array}$ & $\begin{array}{l}1333.29 \\
( \pm \\
55.88)\end{array}$ & 0.149 \\
\hline $\begin{array}{l}\text { Refined } \\
\text { grains }\end{array}$ & $\begin{array}{l}\text { Bread (milk, fried, oily, or sugar } \\
\text { bread), lavash, baguette, wheat } \\
\text { flour, rice, pasta, noodles, } \\
\text { vermicelli, crackers }\end{array}$ & - & 0.392 & $\begin{array}{l}271.78 \\
( \pm \\
17.76)\end{array}$ & $\begin{array}{l}247.14 \\
( \pm \\
16.80)\end{array}$ & 0.120 \\
\hline $\begin{array}{l}\text { French } \\
\text { fries and } \\
\text { potato } \\
\text { chips }\end{array}$ & French fries, potato chips & - & 0.315 & $\begin{array}{l}2.52( \pm \\
0.58)\end{array}$ & $\begin{array}{l}0.38( \pm \\
0.04)\end{array}$ & 0.184 \\
\hline $\begin{array}{l}\text { Sugars, } \\
\text { sweets } \\
\text { and } \\
\text { desserts }\end{array}$ & $\begin{array}{l}\text { Types of cakes, dry or wet } \\
\text { sweets, chocolates, homemade } \\
\text { halva, puff pastry, biscuits, } \\
\text { donuts, caramel cream, sugar, } \\
\text { sugar or cheese, candy, honey, } \\
\text { jams, sugary halva, quotes, } \\
\text { candy, turmeric, sohan }\end{array}$ & - & 0.788 & $\begin{array}{l}28.47 \\
( \pm 4.50)\end{array}$ & $\begin{array}{l}9.49( \pm \\
4.12)\end{array}$ & $\dot{0.001}$ \\
\hline
\end{tabular}

All data are mean $( \pm S D)$ for quantitative variables

${ }^{*}$ Factor loadings $<0.30$ were not listed in the table for simplicity. 


\begin{tabular}{|c|c|c|c|c|c|c|}
\hline \multirow{2}{*}{$\begin{array}{l}\text { Food } \\
\text { groups }\end{array}$} & \multirow[t]{2}{*}{ Major food items in Iran } & \multicolumn{2}{|c|}{ Dietary patterns ${ }^{*}$} & \multirow{2}{*}{$\begin{array}{l}\text { Cases } \\
(n= \\
120)\end{array}$} & \multirow{2}{*}{$\begin{array}{l}\text { Controls } \\
(n= \\
120)\end{array}$} & \multirow{2}{*}{$\begin{array}{l}\mathrm{P} \\
\text { value }\end{array}$} \\
\hline & & $\begin{array}{l}\text { Pattern } \\
\text { 1: } \\
\text { healthy }\end{array}$ & $\begin{array}{l}\text { Pattern } \\
\text { 2: } \\
\text { quasi- } \\
\text { western }\end{array}$ & & & \\
\hline $\begin{array}{l}\text { Pickles } \\
\text { and } \\
\text { salinity }\end{array}$ & Pickles and salinity & - & - & $\begin{array}{l}219.41 \\
(\underline{ \pm} \\
17.96)\end{array}$ & $\begin{array}{l}222.96 \\
( \pm \\
13.38)\end{array}$ & 0.894 \\
\hline $\begin{array}{l}\text { Solid oils } \\
\text { and } \\
\text { animal fat }\end{array}$ & $\begin{array}{l}\text { Margarine, butter, solid vegetable } \\
\text { oil, animal oil, tallow, } \\
\text { mayonnaise }\end{array}$ & -0.454 & - & $\begin{array}{l}102.66 \\
( \pm 9.17)\end{array}$ & $\begin{array}{l}56.30 \\
( \pm 8.36)\end{array}$ & $\dot{0.001}$ \\
\hline Liquid oils & Types of liquid, olive, or green oil & 0.479 & - & $\begin{array}{l}25.99 \\
( \pm 7.19)\end{array}$ & $\begin{array}{l}32.01 \\
( \pm 5.49)\end{array}$ & 0.059 \\
\hline Tomato & Tomatoes, red sauce & 0.701 & - & $\begin{array}{l}36.33 \\
( \pm 7.99)\end{array}$ & $\begin{array}{l}471.29 \\
( \pm 5.37)\end{array}$ & $\begin{array}{l}<.001 \\
0.00\end{array}$ \\
\hline Salt & Table salt, food salt & -0.392 & 0.376 & $\begin{array}{l}4.90 \\
1.77)\end{array}( \pm$ & $\begin{array}{l}3.32( \pm \\
1.24)\end{array}$ & $\begin{array}{l}<.001 \\
0.00\end{array}$ \\
\hline \multicolumn{7}{|c|}{ All data are mean $( \pm S D)$ for quantitative variables } \\
\hline $\mathrm{F}$ & $=0$ & & & & & \\
\hline
\end{tabular}

\section{Table 4}

Final analysis model of the association between food security and other important risk factors with PCOS

\begin{tabular}{|c|c|c|c|}
\hline Factors & & OR (95\% Cl) & $P$ value \\
\hline \multirow[t]{2}{*}{ Food security } & Insecure & 1 & \multirow[t]{2}{*}{0.001} \\
\hline & Secure & $2.665(1.461-4.860)$ & \\
\hline \multirow[t]{2}{*}{ Waist circumference $(\mathrm{cm})$} & $\leq 97$ & 1 & \multirow[t]{2}{*}{0.004} \\
\hline & $>97$ & $2.262(1.301-3.933)$ & \\
\hline \multirow[t]{2}{*}{ MET-hour } & $>1.33$ & 1 & \multirow[t]{2}{*}{0.006} \\
\hline & $\leq 1.33$ & $2.165(1.244-3.769)$ & \\
\hline
\end{tabular}


Table 5

Association between dietary patterns and other important risk factors with PCOS

\begin{tabular}{|c|c|c|c|c|}
\hline \multicolumn{2}{|l|}{ Factors } & \multirow{2}{*}{$\begin{array}{l}\text { OR }(95 \% \mathrm{Cl}) \\
0.163(0.103-0.256)^{*}\end{array}$} & \multirow{2}{*}{$\begin{array}{l}\beta^{\#} \\
-1.817^{*}\end{array}$} & \multirow{2}{*}{$\begin{array}{l}\text { P value } \\
<0.001\end{array}$} \\
\hline Dietary patterns & Healthy & & & \\
\hline & & $0.140(0.085-0.230)^{\star \star}$ & $-1.969^{\star *}$ & \\
\hline & Quasi-western & $32.754(13.249-80.973)^{*}$ & $3.489^{\star}$ & $<0.001$ \\
\hline & & $51.890(18.140-148.43)^{\star \star}$ & $3.949^{\star *}$ & \\
\hline Waist circumfere & cm) & $1.041(1.001-1.082)$ & 0.040 & 0.043 \\
\hline Menstrual age (y & & $1.409(1.128-1.760)$ & 0.343 & 0.003 \\
\hline Low economic le & & $6.886(2.745-17.275)$ & 1.930 & $<0.001$ \\
\hline MET-hour & & $0.008(0.000-0.194)$ & -4.791 & 0.003 \\
\hline \multicolumn{5}{|c|}{ Abbreviations: OR Odds ratio, $\mathrm{C} /$ Confidence interval, $\mathrm{cm}$ centimeter, $M E T$ Metabolic equivalents } \\
\hline \multicolumn{5}{|c|}{${ }^{\#} \beta$ is a standardized regression coefficient that its negative value indicates a risk reduction. } \\
\hline $\begin{array}{l}{ }^{*} \text { Association bet } \\
{ }^{* *} \text { multivariate los }\end{array}$ & $\begin{array}{l}\text { he dietary patt } \\
\text { egression mod }\end{array}$ & PCOS according to the $u$ & analys & els and \\
\hline
\end{tabular}

\section{Figures}




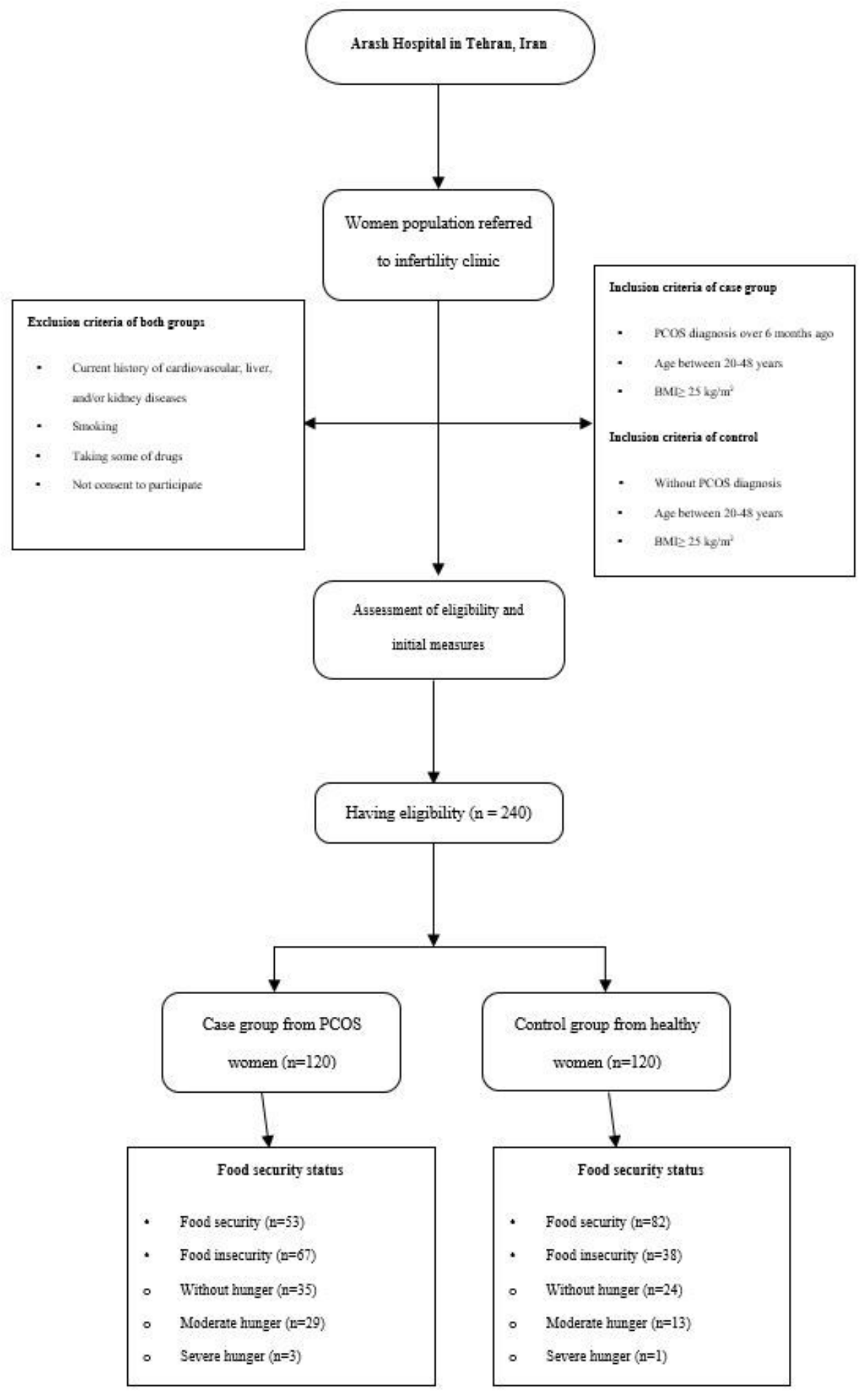

Figure 1

Study flowchart 


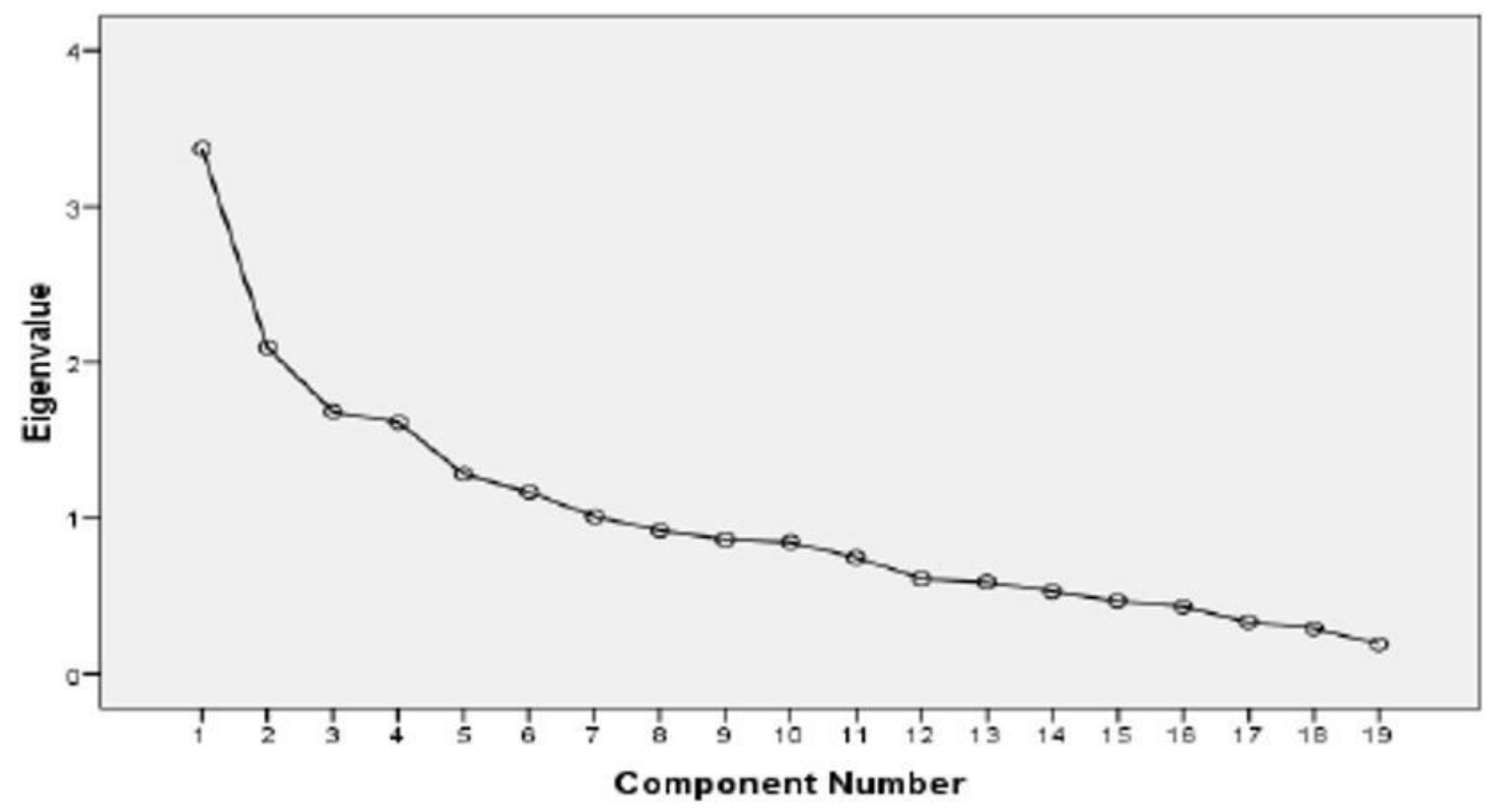

Figure 2

Scree Plot diagram of identifying main dietary patterns 